\title{
Escalation Of Commitment In MIS Projects: A Meta-Analysis
}

Mayur S. Desai, Texas Southern University, USA

Dmitriy V. Chulkov, Indiana University Kokomo, USA

\begin{abstract}
Escalation of commitment emerged as a major explanation for the propensity of management information systems projects to exceed time and budget constraints. Earlier studies demonstrated that escalation in MIS is a common event. This study presents a meta-analysis of the various theories of escalation that allows for integration of the various escalation factors into a model of irrational escalation and a model of rational escalation. The implications of rational and irrational escalation for the decision making in management of information systems are discussed.
\end{abstract}

Keywords: Escalation of Commitment, Self-Justification, Prospect Theory, Agency Theory, Sunk Costs, Real Options

\section{INTRODUCTION}

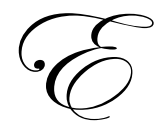

scalation of commitment is a phenomenon that involves continued commitment of resources to a project after the decision maker receives negative feedback about the project's performance (Brockner, 1992). There is a great deal of attention paid to the study of escalation of commitment in the management literature. The seminal study of escalation by Staw (1976) introduced the concept of self-justification as an explanation to escalation of commitment. In this study agents with high personal responsibility for the project were more likely to escalate after getting negative feedback about the project due to the need to justify the original decision in order to appear capable or competent to complete a task. Staw (1981) concludes that escalation is a common event and that "individuals have the tendency to become locked in to a course of action, throwing good money after bad or committing new resources to a losing course of action."

Escalation has been linked to significant losses due to project failures and delays in the area of management information systems (MIS). A report by the Standish Group (2004) collected project completion statistics on over 40,000 MIS projects over the period from 1994 to 2004, and concluded that fifteen percent of MIS projects are cancelled while over fifty percent exhibit significant time and cost overruns. The report estimated that losses due to lost value and cost overruns in these MIS projects reached $\$ 55$ billion in the U.S. in 2004. A number of case studies of escalation detail the extent of the losses that may be associated with escalated projects. Monteleagre and Keil (2000) discuss the development of an automated baggage handling system for the Denver International Airport. This project faced numerous instances of negative feedback, and was completed 16 months behind schedule and $\$ 2$ billion over budget. In another example, the Statewide Automated Child Support System (SACSS) developed in California from 1992 faced a number of negative signals over five years after it was started (Newcombe, 1998; Keil, Mann and Rai, 2000). The project was ultimately cancelled following $\$ 100$ million in direct spending and \$345 million in various reported costs. Keil, Mann and Rai (2000) report that between 30 and 40 percent of all MIS projects demonstrate some degree of escalation.

While escalation of commitment is a general phenomenon that can occur with any type of project, several studies (Zmud, 1980; DeMarco, 1982, Abdel-Hamid, 1988) suggest that MIS projects are particularly prone to escalation. Table 1 presents a meta-analysis of the existing studies of escalation relevant to the MIS literature. Case studies of escalation in MIS have been provided by Keil (1995) and Drummond (1994), among others. Escalation research has identified a number of factors that can cause managers to become entrapped in failing course of action, and provided a number of sequential process theories (Mahring \& Keil, 2008). However, there is no clear distinction 
between the rational and the irrational determinants of escalation. In general, the managerial literature views escalation as an irrational process that reduces the value of a project to the firm due to the influence of psychological and organizational factors such as self-justification. In contrast, economic research attempts to identify factors that make the escalation decision rational for either the decision maker or the firm. Such economic factors as the value of the real options embedded in a project (Tiwana et al., 2006) or the value of sequential investigation of projects quantified by the bandit process theory (Chulkov and Desai, 2005) may make escalation the optimal course of action for the firm. Agency theory demonstrates that escalation may be suboptimal for the firm, but optimal for the manager in the presence of asymmetric information and the principal-agent conflict of interest. Stopping a project may damage the reputation of the manager in charge of the project, which provides incentives to continue failing projects in this setting. This study performs a meta-analysis of escalation research and summarizes the findings in two models of escalation - the irrational escalation model, and the rational escalation model. The antecedents and the implications of these two models for the management of information system (IS) and information technology (IT) projects differ and are discussed in this study.

\section{META-ANALYSIS OF ESCALATION STUDIES}

\begin{tabular}{|c|c|c|c|}
\hline \multicolumn{4}{|c|}{ Table 1: Meta-Analysis of Research in Escalation of Commitment } \\
\hline Theory & Source & Findings & Summary of Implications \\
\hline $\begin{array}{l}\text { Self - } \\
\text { Justification } \\
\text { Theory }\end{array}$ & Staw, 1976 & $\begin{array}{l}\text { Decision makers are motivated to rectify past } \\
\text { losses and attempt to rationalize their actions or } \\
\text { psychologically defend themselves against an } \\
\text { apparent error in judgment. Internal self- } \\
\text { justification causes an individual to desire "to } \\
\text { restore consistency between the consequences of } \\
\text { his actions and a self-concept of rational decision- } \\
\text { making" (Staw, 1976). External self-justification } \\
\text { involves the need of a decision maker to appear } \\
\text { rational in his or her decisions to other } \\
\text { stakeholders such as supervisors. }\end{array}$ & $\begin{array}{l}\text { Self-justification is the } \\
\text { primary explanation for } \\
\text { escalation of commitment. } \\
\text { Self-justification promotes } \\
\text { escalation when the same } \\
\text { decision-maker is responsible } \\
\text { for making the project } \\
\text { selection and the project } \\
\text { continuation decisions. } \\
\text { Rotation of duties and } \\
\text { monitoring may alleviate this } \\
\text { factor. }\end{array}$ \\
\hline $\begin{array}{l}\text { Norms for } \\
\text { Consistency }\end{array}$ & $\begin{array}{l}\text { Staw, } 1981 \\
\text { Staw and Ross, } \\
1980\end{array}$ & $\begin{array}{l}\text { Staw (1981) argues that consistent administrators } \\
\text { are viewed as better leaders. } \\
\text { Staw and Ross's (1980) experimental study } \\
\text { suggests that such norms for consistency are } \\
\text { strongest among practicing administrators and } \\
\text { business students. }\end{array}$ & $\begin{array}{l}\text { Staw (1981) suggests that the } \\
\text { perception that consistent } \\
\text { managers are stronger may be } \\
\text { acquired through } \\
\text { socialization in business roles } \\
\text { leading to the proneness to } \\
\text { escalation among decision- } \\
\text { makers. }\end{array}$ \\
\hline $\begin{array}{l}\text { Organizational } \\
\text { Inertia }\end{array}$ & Brockner, 1992 & $\begin{array}{l}\text { Brockner (1992) discusses the application of } \\
\text { organizational inertia theories to escalation. With } \\
\text { organizational inertia, even when the need to } \\
\text { terminate a project is recognized, it is not acted } \\
\text { upon immediately. }\end{array}$ & $\begin{array}{l}\text { With organizational inertia } \\
\text { the need to stop an escalating } \\
\text { project is recognized, but the } \\
\text { organization is incapable of } \\
\text { swift action. }\end{array}$ \\
\hline $\begin{array}{l}\text { Prospect } \\
\text { Theory }\end{array}$ & Whyte, 1986 & $\begin{array}{l}\text { Prospect theory (Kahnemann and Tversky, 1979) } \\
\text { provides an alternative to self-justification } \\
\text { processes. Under the prospect theory, individuals } \\
\text { exhibit risk-averse behavior when the decision is } \\
\text { framed positively, and risk-seeking behavior when } \\
\text { the decision is framed negatively. It implies that } \\
\text { the negative framing of decision as a choice } \\
\text { between losses may induce investment decisions } \\
\text { that are irrational for a risk-averse or risk-neutral } \\
\text { decision maker. }\end{array}$ & $\begin{array}{l}\text { Prospect theory unlike self- } \\
\text { justification, suggests that the } \\
\text { framing of decision is critical } \\
\text { in promoting escalation. } \\
\text { Personal responsibility for } \\
\text { the original selection is not } \\
\text { required under prospect } \\
\text { theory. }\end{array}$ \\
\hline $\begin{array}{l}\text { Sunk Cost } \\
\text { Effect }\end{array}$ & $\begin{array}{l}\text { Arkes and Blumer, } \\
1985 \\
\text { Garland, } 1990\end{array}$ & $\begin{array}{l}\text { The sunk cost effect is the propensity of managers } \\
\text { to continue funding for a project when a large } \\
\text { amount of money has already been committed to } \\
\text { the project. The sunk cost effect is closely relate }\end{array}$ & $\begin{array}{l}\text { Sunk cost effect may promote } \\
\text { escalation when large } \\
\text { amounts of sunk spending are } \\
\text { involved. }\end{array}$ \\
\hline
\end{tabular}




\begin{tabular}{|c|c|c|c|}
\hline & $\begin{array}{l}\text { Garland, Sandefur, } \\
\text { Rogers, } 1990\end{array}$ & $\begin{array}{l}\text { to escalation. A major explanation for the sunk } \\
\text { cost effect is the prospect theory. As withdrawal } \\
\text { from a course of action may lead to the sunk costs } \\
\text { being viewed as a certain loss, the decision } \\
\text { makers become more reluctant to withdraw as } \\
\text { sunk costs increase. } \\
\text { Experimental evidence is presented that strong } \\
\text { negative feedback and professional experience } \\
\text { may reduce sunk cost effect. }\end{array}$ & \\
\hline $\begin{array}{l}\text { Approach } \\
\text { Avoidance } \\
\text { Theory }\end{array}$ & $\begin{array}{l}\text { Rubin and } \\
\text { Brockner, } 1975 \\
\text { Brockner and } \\
\text { Rubin, } 1985\end{array}$ & $\begin{array}{l}\text { Escalation may be presented as an instance of } \\
\text { approach avoidance conflict. Under approach } \\
\text { avoidance theory, escalation behavior results } \\
\text { when driving forces that encourage persistence } \\
\text { prevail over restraining forces that encourage } \\
\text { abandonment (Brockner and Rubin, 1985). These } \\
\text { competing forces create a conflict over whether to } \\
\text { continue or withdraw. The forces that encourage } \\
\text { persistence include the size of the reward for goal } \\
\text { attainment, the cost of withdrawal, and the } \\
\text { proximity to the goal. } \\
\text { The empirical study by Conlon and Garland } \\
\text { (1993) suggests that the completion effect } \\
\text { associated with approach avoidance theory may } \\
\text { have a more pronounced impact on escalation } \\
\text { behavior than the sunk cost effect. }\end{array}$ & $\begin{array}{l}\text { Escalation may be more } \\
\text { common in the presence of } \\
\text { the forces promoting } \\
\text { persistence, including the } \\
\text { proximity of the goal. }\end{array}$ \\
\hline $\begin{array}{l}\text { Agency } \\
\text { Theory }\end{array}$ & $\begin{array}{l}\text { Kanodia, Bushman, } \\
\text { and Dickhaut, } 1989 \\
\text { Keil, Mann, and } \\
\text { Rai, } 2000 \\
\text { Harrison and } \\
\text { Harrell, } 1993\end{array}$ & $\begin{array}{l}\text { Agency theory focuses on the relationship } \\
\text { between someone who delegates work (the } \\
\text { principal) and another individual (the agent) who } \\
\text { performs that work. Escalation behavior occurs as } \\
\text { the agent follows a course of action that is in the } \\
\text { agent's best interest, but is irrational from the } \\
\text { principal's perspective. } \\
\text { Through a laboratory experiment, Harrison and } \\
\text { Harrell (1993) showed that subjects are more } \\
\text { likely to continue a failing project in the } \\
\text { experimental condition when they were } \\
\text { manipulated to believe that they possessed private } \\
\text { information about the project's likelihood of } \\
\text { success and that a decision to terminate the project } \\
\text { would damage their reputation. These findings } \\
\text { were interpreted to be consistent with an agency } \\
\text { theory view of escalation. Subsequent studies } \\
\text { have yielded similar results (Harrell and Harrison, } \\
\text { 1994). }\end{array}$ & $\begin{array}{l}\text { Agency theory implies that } \\
\text { there is a conflict of interests } \\
\text { between the principal and the } \\
\text { agent. Escalation occurs } \\
\text { when the decision to continue } \\
\text { the project is rational for the } \\
\text { agent due to reputation- } \\
\text { protection or monetary } \\
\text { concerns. Escalation is } \\
\text { rational for the agent, but } \\
\text { irrational for the firm. }\end{array}$ \\
\hline Bandit Theory & $\begin{array}{l}\text { Chulkov and Desai, } \\
2005\end{array}$ & $\begin{array}{l}\text { Bandits are a class of decision-making problems } \\
\text { that involve choosing one action from a set of } \\
\text { available alternatives. In terms of project } \\
\text { management, the firm selects from several } \\
\text { alternative IT projects, each with its own } \\
\text { distribution of risks and rewards. In this problem, } \\
\text { only one technology choice may be implemented } \\
\text { by the firm in every given period and only the best } \\
\text { performing technology is kept by the firm. When } \\
\text { facing the bandit problem, managers choosing a } \\
\text { risky IT project with a high potential reward } \\
\text { before a safer one are behaving optimally and in } \\
\text { the firm's interest. It is better to resolve the }\end{array}$ & $\begin{array}{l}\text { The bandit problem provides } \\
\text { the incentive to invest in } \\
\text { risky projects first, even } \\
\text { when they are associated with } \\
\text { negative feedback. Since the } \\
\text { successful technology is kept } \\
\text { by the firm, going for the } \\
\text { safer options first will leave } \\
\text { the high-risk high-reward } \\
\text { projects unexplored. High- } \\
\text { risk projects may be } \\
\text { associated with negative } \\
\text { feedback, and thus with }\end{array}$ \\
\hline
\end{tabular}




\begin{tabular}{|c|c|c|c|}
\hline & & $\begin{array}{l}\text { uncertainty about the innovative project first. } \\
\text { Firms that face the bandit problem of technology } \\
\text { choice may appear to engage in escalation, as } \\
\text { following the optimal strategy in the bandit } \\
\text { problem requires risky investment. }\end{array}$ & $\begin{array}{l}\text { escalation. } \\
\text { uncertainty about these high- } \\
\text { risk projects is rational for } \\
\text { the firm. }\end{array}$ \\
\hline $\begin{array}{l}\text { Real Option } \\
\text { Theory }\end{array}$ & $\begin{array}{l}\text { Benaroch and } \\
\text { Kauffman, } 1999 \\
\text { Chulkov and Desai, } \\
2008 \\
\text { Tiwana, Keil, and } \\
\text { Fichman, 2006 }\end{array}$ & $\begin{array}{l}\text { Real options are embedded in a project when the } \\
\text { decision maker has the opportunity but not the } \\
\text { obligation to adjust the future direction of the } \\
\text { project in response to external or internal events. } \\
\text { Real options are common in MIS projects. } \\
\text { Continuation of the project has value when there } \\
\text { is uncertainty and new information about the } \\
\text { project may be revealed. Failure to account for the } \\
\text { real option value in a project is value-reducing for } \\
\text { the firm as it may lead to mistakes in premature } \\
\text { termination of projects when projects with real } \\
\text { option value are labeled as cases of irrational } \\
\text { escalation. } \\
\text { Experimental data collected from managers in } 123 \\
\text { firms demonstrated that managers recognize and } \\
\text { value the presence of real options. } \\
\text { The various option types encountered in IS } \\
\text { development include: the option to switch use - } \\
\text { the opportunity to use the IS for an additional } \\
\text { purpose from that for which it was originally } \\
\text { intended; the option to change scale that allows } \\
\text { the scope of the application to be extended or } \\
\text { contracted in the future; the option to stage } \\
\text { investments that exists when a project is structured } \\
\text { as a series of incremental outlays that allows the } \\
\text { project to be terminated when negative } \\
\text { information about its prospects is revealed; the } \\
\text { abandonment option that involves the opportunity } \\
\text { to stop the project and redeploy resources without } \\
\text { major negative effects on the firm; and the growth } \\
\text { option that is associated with a project when an } \\
\text { initial investment leads to a variety of potential } \\
\text { additional investments in the future. }\end{array}$ & $\begin{array}{l}\text { Real option theory provides a } \\
\text { sharp contrast to } \\
\text { psychological and } \\
\text { organizational theories of } \\
\text { irrational escalation. Under } \\
\text { the real option theory, } \\
\text { continuing a project has value } \\
\text { for the firm due to various } \\
\text { real options associated with } \\
\text { the project. Failure to account } \\
\text { for real option value leads to } \\
\text { premature termination of } \\
\text { projects that still have value } \\
\text { for the firm. Such projects } \\
\text { may be labeled as cases of } \\
\text { escalation, even though } \\
\text { continuation of these projects } \\
\text { is rational once the real } \\
\text { option value is incorporated } \\
\text { in the decision making. }\end{array}$ \\
\hline
\end{tabular}

\section{IMPLICATIONS FOR MANAGEMENT OF INFORMATION SYSTEMS}

Research on escalation of commitment in general, and the escalation of MIS projects in particular has covered a wide area of psychological, organizational, and economic theories. Recent developments such as the process theories of escalation (Mahring and Keil, 2008) emphasize the complex nature of the escalation process. The factors that are responsible for escalation can be classified into two broad groups - the irrational escalation factors and the rational escalation factors. The former include determinants of escalation that is irrational for both the manager and the firm. The latter focus on the rational reasons to continue the project after negative feedback. Such reasons may make escalation rational for only the manager if there is a conflict between the manager and the firm as noted by the agency theory. We attempt to summarize the escalation determinants into a model of irrational escalation and a model of rational escalation. 


\section{Irrational Escalation Model}

In the irrational escalation model, continuation of the project is truly a mistake, as it is not in the best interest of either the firm, or the manager. The escalation phenomenon is often seen as a puzzle, as the best course of action after receiving negative feedback is to terminate the project. This view adopts the irrational approach to escalation. The meta-analysis of escalation studies identified six major theories that focus on the irrational forces behind escalation.

The psychological theories include the self-justification, the approach-avoidance, and the prospect theory, as well as the closely related "sunk-cost effect". The social and organizational forces behind irrational escalation include the norms for consistency and the presence of organizational inertia. Figure 1 summarizes the forces that contribute to irrational escalation.

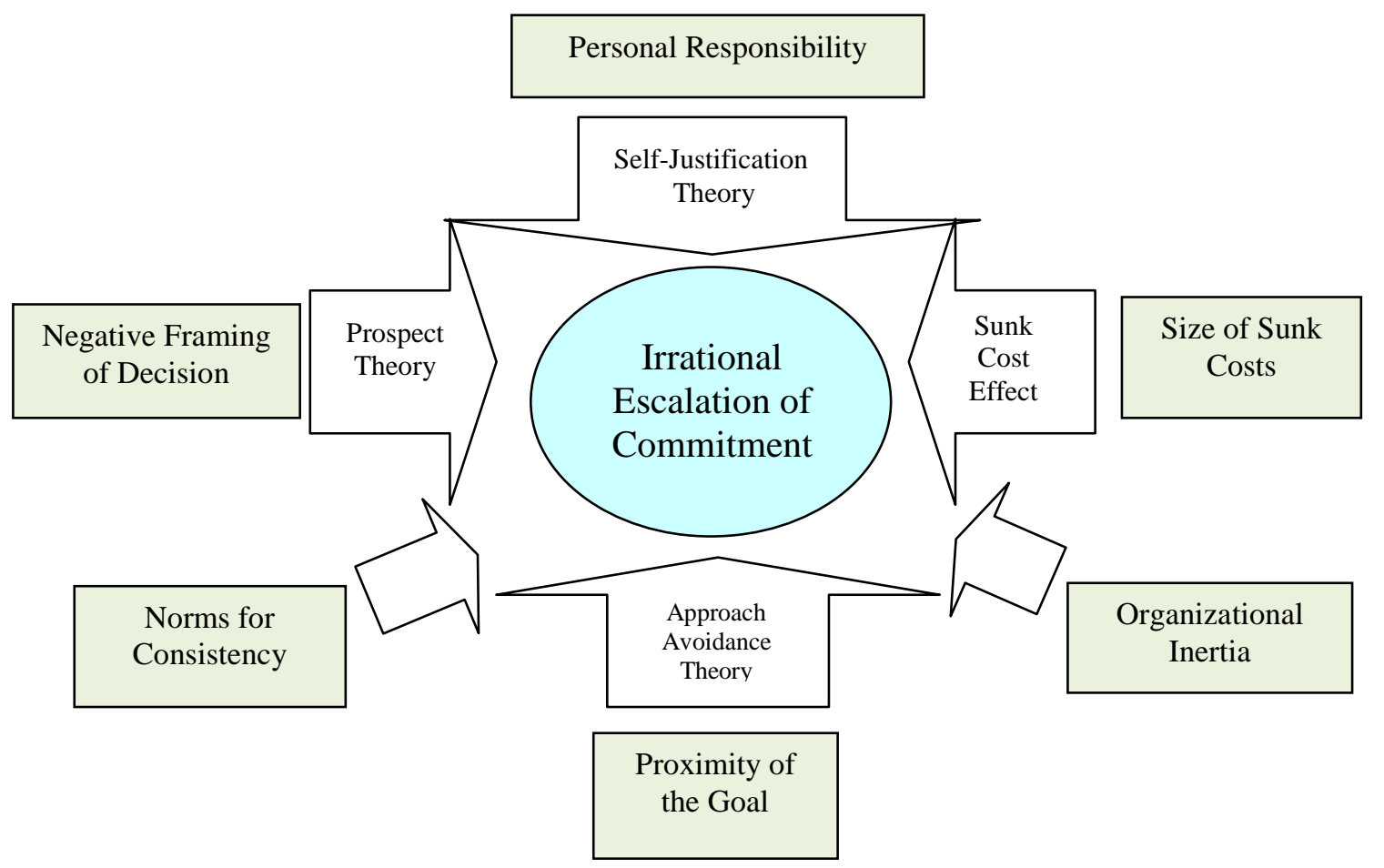

Figure 1. Irrational Escalation Model

In summarizing the factors that promote escalation, the irrational escalation model has important implications for the management of information systems projects. Once the firm understands the forces that contribute to irrational escalation, the problem of IT project waste may be mitigated. The process of stopping escalated projects and reversing escalation, known as de-escalation, is characterized by the recognition of the problem, re-examination of the project, and search for alternative options (Monteleagre and Keil, 2000). Deescalation has been associated with such factors as the change in the management of the project and improved governance mechanisms including monitoring and regular evaluations of the project's progress (Keil and Robey, 1999). Among others, Kim and Park (2007) indicate that an important determinant of de-escalation is the presence of control mechanisms such as the Capability Maturity Model (CMM).

De-escalation techniques should be emphasized for projects that exhibit the presence of escalation factors identified in Figure 1, including the personal responsibility of managers for both the project selection and project 
continuation decisions, the potential for negative framing of decision options due to large sunk costs, the large size of organization and the presence of organizational inertia. If the project development encounters one or more of these escalation factors, application of de-escalation techniques is warranted and may lead to improvement in project development success rate and the reduction of waste due to escalation errors.

\section{Rational Escalation Model}

An important insight from the meta-analysis of escalation studies is the fact that some escalation in the sense of continuation of a project following negative feedback is in the best interest of the firm. Escalation is rational if it is justified by the value that the firm receives from investigating the project further. Keil and Mann (1997) report that a large share of IS projects, as many as 40 percent, are associated with some degree of escalation. It is difficult to argue that so many IS projects involve irrational errors in judgment. Some of these cases of escalation may be rational for the firm. The real option theory and the bandit theory provide examples when project continuation is justified by the value of information and the value of flexibility that the firm receives from continuing the project.

In contrast, the agency theory focuses on the conflict of interest between the agent (manager) and the principal (firm). The decision to continue the project may be irrational for the firm, but rational for the manager. One reason is provided by the need to protect reputation. The manager in charge of the project is often the first to discover the project's true chances for success. If the manager finds out that the project is failing and terminates the project that he or she earlier selected, this would signal that a mistake was made. The reputation of the manager would be damaged. If the future wages and career concerns of the manager depend on this reputation, there is an incentive to continue the project (Kanodia et al., 1989). Another source of incentives to continue the project is the nature of incentives for the agent. If the agent is compensated based solely on the performance of the project, than there is the incentive to conceal negative information and delay termination of the project, as the compensation of the agent would be reduced by any action that reveals negative information. This provides the rationale for compensating managers based on their decision process, and not only on the outcome.

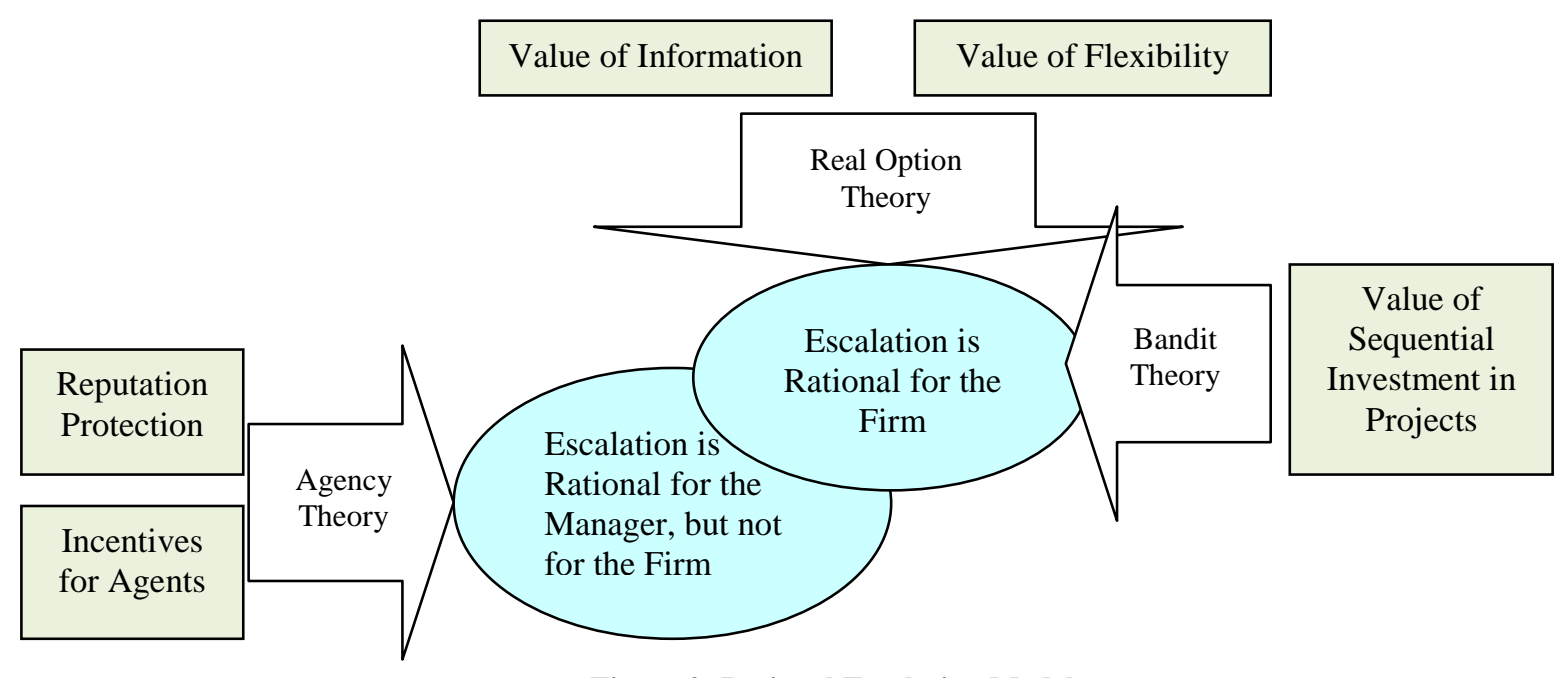

Figure 2: Rational Escalation Model

When the projects at the firm are associated with factors that promote irrational escalation, as discussed in Figure 1, the use of de-escalation mechanisms may improve the performance of the firm. However, aggressive application of de-escalation techniques may lead to the termination of projects that may ultimately turn out to be successful. Figure 2 summarizes the factors that are associated with rational escalation and highlights the factors that may provide value for the firm and make project termination premature. First, the real option theory suggests that 
future flexibility adds value to the project. The real option theory applies when there is uncertainty about the project, and continuing the project may yield new information or provide future growth opportunities for the firm. In this case, escalation in the sense of continuing the project is optimal for the firm, and a termination will be premature. Second, the bandit theory implies that the sequential nature of investigating alternative technological solutions yields value for trying the high-risk high-reward projects first. This result depends on the design of the bandit problem in which the firm chooses between several alternative technologies under conditions of uncertainty. The critical feature is that only one technology choice is implemented by the firm each period and only one is ultimately used. The optimal solution for the bandit problem involves investigating high-risk high-reward technologies fully before opting for a low-risk low-reward solution. De-escalation mechanisms that guide managers toward low-risk projects may not be in the best interest of the firm as they will cause high-reward projects to remain unexplored.

\section{CONCLUSION}

Escalation of commitment is commonly defined as continuation of a project after receiving negative feedback. Such escalation has been explored in a variety of experimental and empirical studies, and is especially common in MIS projects, with as many as 40 percent of all projects exhibiting some degree of escalation (Keil and Mann, 1997; Keil et al., 2000). We present a meta-analysis of escalation studies, and conclude that the literature on escalation may be separated into two broad groups - the studies of irrational escalation and the theories of rational escalation that lead to project continuation patterns even following negative feedback.

We present the model of irrational escalation and the model of rational escalation in order to summarize the factors that promote each type of project continuation decisions. The examination of the irrational escalation model leads to a better understanding of the forces that contribute to irrational escalation, and helps alleviate the problem of IT project waste. If the irrational escalation factors are present in the decision making process involving an MIS project, then de-escalation techniques should be utilized, including a change in the management of the project, rotation of duties, and improved governance mechanisms such as monitoring and regular evaluations of the project's progress. De-escalation techniques should be emphasized for projects that exhibit the presence of escalation factors identified in the irrational escalation model, including the responsibility of the same manager for both the project selection and project continuation decisions that creates proneness to self-justification, the potential for negative framing of decision options due to large sunk costs, the large size of organization and the presence of organizational inertia. If the project development encounters one or more of these escalation factors, application of de-escalation techniques may lead to improvement in project development success rate and the reduction of waste due to escalation errors.

The rational escalation model highlights the fact that some escalation is rational and is in the best interest of both the manager and the firm. The real option theory and the bandit theory provide examples when project continuation is justified by the value of information and the value of flexibility that the firm receives from continuing the project. The agency theory involves escalation that is rational for the manager, but not the firm. Reputation protection and the attempt to escape lower compensation due to the termination of a project may lead the manager to continue a project after negative feedback as long as there is informational asymmetry and the principal of the firm discovers the project status with some delay. Understanding of the incentives behind rational escalation allows the firm to promote project management practices that are in the best interest of the firm.

\section{AUTHOR INFORMATION}

Mayur S. Desai earned Ph.D. in Business Computer Information Systems from University of North Texas. He spent nine years at Indiana University Kokomo before joining Texas Southern University. His research interests include end-user development, ethics in information systems, and managing information systems.

Dmitriy V. Chulkov is the Associate Professor of Economics and Management Information Systems at Indiana University Kokomo. His research interests include the economics of escalation in management information systems, and economics of information. Dr. Chulkov earned his doctorate from the Krannert Graduate School of Management at Purdue University. 


\section{REFERENCES}

1. Abdel-Hamid, T. K. (1988) Understanding the '90\% Syndrome' in Software Project Management: A Simulation-Based Case Study. The Journal of Systems and Software, 8 (4), 319-330.

2. Arkes, H., Blumer, C. (1985). The Psychology of Sunk Cost. Organizational Behavior and Human Decision Processes, 35, 124-140.

3. Benaroch, M., Kauffman, R. (1999) A Case for Using Real Options Pricing Analysis to Evaluate Information Technology Project Investments, Information Systems Research, 10 (1), 70-86.

4. Brockner, J. (1992) The Escalation Of Commitment to a Failing Course of Action: Toward Theoretical Progress. Academy of Management Review, 17 (1), 39-61.

5. Brockner, J., and Rubin, J. (1985) Entrapment in Escalating Conflicts: A Social Psychological Analysis, Springer-Verlag: New York.

6. Chulkov, D. and Desai, M. (2008). Escalation and Premature Termination in MIS Projects: The Role of Real Options. Information Management and Computer Security, 16 (4), 324-335.

7. Chulkov, D. and Desai, M. (2005) Information Technology Project Failures: Applying the Bandit Problem to Evaluate Managerial Decision Making. Information Management and Computer Security, 13 (2), 135143.

8. Conlon, D., Garland, H. (1993) The Role of Project Completion Information in Resource Allocation Decisions. Academy of Management Journal, 36 (2), $402-413$.

9. DeMarco, T. (1982) Controlling Software Projects. Yourdon Press: New York.

10. Drummond, H. (1994) Too Little Too Late: A Case Study of Escalation in Decision Making. Organization Studies. 15 (4), 591-607.

11. Garland, H. (1990). Throwing Good Money after Bad: The Effect of Sunk Costs on the Decision to Escalate Commitment to an Ongoing Project. Journal of Applied Psychology, 75, 728-731.

12. Garland, H., Sandefur, C., Rogers, A. (1990) De-Escalation of Commitment in Oil Exploration: When Sunk-Costs and Negative Feedback Coincide. Journal of Applied Psychology, 75, 721-727.

13. Harrell, A., Harrison, P. (1994) An Incentive to Shirk, Privately Held Information, and Managers' Project Evaluation Decisions. Accounting, Organizations and Society, 19 (7), 569-577.

14. Harrison, P., Harrell, A. Impact of 'Adverse Selection' on Managers' Project Evaluation Decisions. Academy of Management Journal, 36 (3), 635-643.

15. Kahneman, D., Tversky, A. (1979) Prospect Theory: Analysis of Decisions under Risk. Econometrica, 47, 263-291.

16. Kanodia, C., R. Bushman, Dickhaut, J. (1989) Escalation Errors and the Sunk Cost Effect: An Explanation Based on Reputation and Information Asymmetries. Journal of Accounting Research, 27 (1), 59-77.

17. Keil, M. (1995) Pulling the Plug: Software Project Management and the Problem of Project Escalation. MIS Quarterly, 19 (4), 421-447.

18. Keil, M., Mann, J. (1997) The Nature and Extent of IT Project Escalation: Results From a Survey of IS Audit and Control Professionals. IS Audit and Control Journal, 1, 40-48.

19. Keil, M., Mann, J., and Rai, A. (2000) Why Software Projects Escalate: An Empirical Analysis and Test of Four Theoretical Models. MIS Quarterly, 24 (4), 631-664.

20. Keil, M. and Robey, D. (1999) Turning Around Troubled Software Projects: An Exploratory Study of Deescalation of Commitment to Failing Courses of Action. Journal of Management Information Systems, 15, (4), 63-87.

21. Kim, E., Park, Y. (2007) Prediction of IS Project Escalation Based on Software Development Risk Management. Journal of Information \& Knowledge Management, 6 (2), 153-163.

22. Mahring, M. and M. Keil (2008) Information Technology Project Escalation: A Process Model. Decision Sciences, 39 (2), 239-272.

23. Monteleagre, R. and Keil, M. (2000) De-escalating information technology projects: Lessons from the Denver international airport. MIS Quarterly, 24 (3), 417-447.

24. Newcombe, T. (1998) Big Project Woes Halt Child Support System. Government Technology, Feb. 1998, 34-35.

25. Rubin, J., and Brockner, J. (1975) Factors Affecting Entrapment in Waiting Situations: The Rosencrantz and Guildenstern Effect. Journal of Personality and Social Psychology, 31, 1054-1063.

26. Standish Group (2004) CHAOS Report 2004, https://secure.standishgroup.com/reports/reports.php 
27. Staw, B., (1976) Knee-Deep in the Big Muddy: A Study of Escalating Commitment to a Chosen Course of Action. Organizational Behavior and Human Performance, 16, 27-44.

28. Staw, B. (1981) The Escalation of Commitment to a Course of Action. Academy of Management Review, 6, 577-587.

29. Staw, B. and Ross, J. (1980) Commitment in an Experimenting Society: An Experiment on the Attribution of Leadership from Administrative Scenarios. Journal of Applied Psychology, 65, 249-260.

30. Tiwana, A., Keil, M., Fichman, R. (2006) Information Systems Project Continuation in Escalation Situations: A Real Option Model, Decision Sciences, 37 (3), pp. 357-391.

31. Whyte, G. (1986) Escalating Commitment to a Course of Action: A Reinterpretation. Academy of Management Review, 11 (2), 311-321.

32. Zmud, R. W. (1980). Management of large software efforts. MIS Quarterly, 4, 45-55. 
NOTES 